\title{
The Effectiveness of Shared Reading Strategy toward Students' Reading Achievements
}

\author{
Berni Arnita Hutabarat ${ }^{1}$, Albert Effendi Pohan ${ }^{2}$, Adam $^{3}$ \\ English Education Department \\ University of Riau Kepulauan \\ berniy21042014@gmail.com ${ }^{1}$,guruindonesia31@gmail.com², ayamezhu@gmail.com ${ }^{3}$
}

\begin{abstract}
Many students got difficulty in reading descriptive text, especially who lack on vocabulary. To acquire the students' reading comprehension, it is needed to stimulate the students' mind and corrective feedback. Thus, to solve this problem, the writer tried to teach reading descriptive text by using Shared Reading Strategy to make the reading activity in the classroom more effective and could improve students' reading comprehension. The writer conducted this teaching media in process of reading descriptive text at class VII-A at SMP Tunas Baru Jin - Seung Batam with 35 samples. This research is a quantitative approach. The method was used in this research is experiment method and focused on Quasi experimental. The research conducted in SMP Tunas Baru Jin - Seung Batam, on April - June 2016 where two classes were taken as the samples of this study. Class VII-A as experimental class and VII-B as control group. The technique of collecting data in this research was pre-test and post-test. The question in pre-test and post-test are similar form. To prove that the alternative hypothesis $(\mathrm{Ha})$ is accepted, the researcher used t-test formula calculate the data. The data gained $T_{\text {test }}>t$ table(31.64>1.667). It also can be seen from both classes post-test mean value; control class' mean was 69 and experimental class' was 78.43. So, it can be concluded that the used of Shared Reading Strategy gives a significant effect in student's reading comprehension.
\end{abstract}

Keywords: students reading comprehension, shared reading strategy.

\section{INTRODUCTION}

Reading is one of the efforts to comprehend the meaning of the text observed. Beside that, reading is not only to pronounce word by word but also to comprehend the information of the text such as explicit and implicit information. In this context the explicit information is any idea that is stated and implicit information is understood but it is not stated. 
Reading is very useful to understand all the lesson taught at school especially for students of junior high school. The students can obtain information, knowledge, pleasure, and broaden their horizon by reading.

The students face English vocabularies, it's means the students did not able understand the word of the texts, they also face reading fluency because they did not able to pronounce word by word correctly and they face difficulties in comprehending the English text they did not able to understand the purpose of the texts. Therefore, they did not comprehending the text. Of these cases, the researcher recommend that teachers are required to have a variety of approaches, models, and strategies to teach reading. One of them shared reading strategies.

Because of many problems that faced by the students in reading. The writer need to limit this problem. This study was limited to the effectiveness of using shared reading strategy toward students' reading achievement. Based on the problem, the writer formulated the problem of the study as follow, does shared reading strategy give significant effect to students' reading achievement at seventh grade of SMP Tunas Baru Jin - Seung Batam in academic year 2015/2016?

The objective of the research is to know whether there is significant influence between the students' reading achievement before and after being taught using Shared Reading Strategy at seventh grade of SMP Tunas Baru Jin - Seung Batam in academic year 2015/2016.

Significance of the study, The result of study expected that the results of the study can help the students at this school realize and increase the student reading achievement by using shared reading strategy. And then for teacher English teacher they can get more references about media in teaching reading. And for the next researchers, they have knowledge about the effect by using pictures in students' ability in teaching or learning English.

\section{METHODOLOGY}

This study conducted to as experimental research. Experimental research is research activity that aims to find out the effect of treatment in condition as an effect of treatment. The method used in this research is experiment research, and focused on quasi experimental design. This study intended to show the significant effect of using individual pictures toward 
students' reading comprehension achievement in descriptive text. According to Sugiyono (2009:77) stated that quasi experimental design is development of true experimental design, that almost same with pretest-posttest control group design.

This research was 8 meetings. In this research, the researcher determined population, sample and sampling technique of the research to make them easier to collected data. It can be concluded that population is all of group member of people, events, or objects which live together in one place from the final conclusion of a research.

\section{Population, Sample and Sampling Technique Population}

Sugiyono (2010:117) explained that population is generalizing territory that consists of object / subject that have certain qualities and characteristics were determined by the researcher to learn and then drawn conclusions. The population of this research is all the seventh grade students of SMP Tunas Baru Jin Seung Batam in academic year 2015 / 2016.

The total number of the population is 175 students. They were distributed into five classes, each class consisted of 35 students. The sample of this study consists of two class, in this research. The sample in this research were class VII-A for experiment class and class VII-B for control class. The specification of the population could be seen on the table below:

Table 1. List of population

\begin{tabular}{lcc}
\hline No & Grade & Total of Students \\
\hline $\mathbf{1 .}$ & VII - A & 35 \\
\hline $\mathbf{2 .}$ & VII - B & 35 \\
\hline 3. & VII - C & 35 \\
\hline $\mathbf{4 .}$ & VII - D & 35 \\
\hline $\mathbf{5 .}$ & VII - E & 35 \\
\hline & Total & $\mathbf{1 7 5}$ \\
\hline
\end{tabular}




\section{Sample}

According to Sugiyono (2010:118) said the sample is part of the number and characteristics owned by the population. That is a small group or subject of the total population in such a way that the knowledge gained is representative of the total population (however defined) under study.

In this research, the writer take two classes as a sample of the research, the population of the study are students at seventh grade in SMP Tunas Baru Jin - Seung Batam. They are the two classes was VII-A as the experimental group and VII-B as the control group

\section{Sampling Technique}

The writer used cluster random sampling. According to Sugiyono (2013:64). The cluster random sampling is area sampling technique that is used to choose the sample if the object or sources of the research are wide.

In order to measure the students' reading comprehension in learning English. It came from the evaluation conducted or test. The test consists of 40 items in multiple choices and the sources of the test was from the book of Junior High School based on the school curriculum. The test was used for pre-test and post-test.

\section{Technique of collecting data}

\section{Instrument}

Instrument is used to measure variable value that is researched. It was more practical for the researcher to do research and result of the research was more valid, so the data could be analyzed more comprehensively.

The instrument of this research is written test in the form of multiple choice. It consist of 40 items that have four options there is A,B,C or D. This research was conducted to find out how the students comprehend their reading by using Shared Reading Strategy (in experimental class), and also to find out the significant effect of the Shared Reading towards students' reading comprehension achievement. There were two data of students' reading achievement by using Shared Reading Strategy and the data of students' reading achievement without using Shared Reading Strategy.

The data of the students' score in reading achievement show that the lowest score of pre-test score in experimental class was 50, the highest score was 85, the mean was 67.43, standard deviation score was 7.71 and variance was 59.37. The data in control class showed 
that the lowest score was 35 , the highest score was 75 , the mean was 54.71 , standard deviation score was 9.47 and variance was 89.62 .

Based on the data above, both pre-test of experimental and control class, data of experimental class was higher than control class.

In the Post test class, the data showed that the lowest score in experimental class was 60, the highest score was 95, the mean was 78.43, standard deviation score was 6.94 and variance was 48.19. And the data in control class showed that the lowest score was 50, the highest score was 85, the mean was 69, standard deviation score was 7.55 and variance was 57.06. Based on the data above, both post-test of experimental and control class, data of experimental class was higher than control class.

\section{RESULTS}

\section{Validity Test}

The result of validity items $r_{\text {calculated }}$ gathered, each items consulted tor $_{\text {table }}$ with $\mathrm{n}=42, \mathrm{r}_{\text {table }}=0.304$. item which has $\mathrm{r}_{\text {calculated }}>\mathrm{r}_{\text {table }}$ called valid item.Based on helping table of test validity items calculated withN $=42$ and $r_{\text {table }}=0.304$

\section{Reliability Test}

The instrument used were multiple choice forms, so that the measurement of reliability items of the research instruments used Kuder Richardson (KR) 20. If $r_{11}>r_{\text {table, so }}$ the data is reliable, and If $r_{11}<\mathrm{r}_{\text {table }}$, so the data is not reliable. Based on the calculation table with 35 students and the total number of valid questions was 20 the significance level is $5 \%$ or 0.05 , so $r_{\text {table }}$ with $n=35$ is 0.334 . Because $r_{\text {observed }}>r_{\text {table }}, 0.84>0.304$, so it can be summarized that the instrument test is reliable.

\section{Normality Test}

Normality testing was analyzed toward two of the data groups, they were reading comprehension descriptive text data of pre-test and reading comprehension descriptive text data post-test. The criteria of normality test is if the $\mathrm{X}^{2}$ observed $<\mathrm{X}^{2}$ table, so the instrument is in normal distribution. 
Table 2. Summary of normality testing

\begin{tabular}{lccc}
\hline \multicolumn{1}{c}{ Variable } & $\mathbf{X}_{\text {observed }}$ & $\mathbf{X}_{\text {table }}$ & Note \\
\hline $\begin{array}{l}\text { Pre-test reading comprehension } \\
\text { of Experimental Class }\end{array}$ & 10.36 & 11.070 & $\mathrm{X}_{\mathrm{o}}<\mathrm{X}_{\mathrm{t}}$ \\
\hline $\begin{array}{l}\text { Pre-test reading comprehension } \\
\text { of Control Class }\end{array}$ & 8.8 & 11.070 & $\mathrm{X}_{\mathrm{o}}<\mathrm{X}_{\mathrm{t}}$ \\
\hline $\begin{array}{l}\text { Post-test reading comprehension } \\
\text { of Experimental Class }\end{array}$ & 6.13 & 11.070 & $\mathrm{X}_{\mathrm{o}}<\mathrm{X}_{\mathrm{t}}$ \\
\hline $\begin{array}{l}\text { Post-test reading comprehension } \\
\text { of Control Class }\end{array}$ & 9.96 & 11.070 & $\mathrm{X}_{\mathrm{o}}<\mathrm{X}_{\mathrm{t}}$ \\
\hline
\end{tabular}

$\mathrm{X}_{\text {observed }}$ was Normal distribution when it is lower than $\mathrm{X}_{\text {table }}\left(\mathrm{X}_{\text {observed }}<\mathrm{X}_{\text {table }}\right.$ ), $\mathrm{X}_{\text {observed }}$ in the Pre-test experimental class was 10.36 and $X_{\text {table }} 11.070$. in the Post-test experimental class the $\mathrm{X}_{\text {observed }}$ was 6.13 and $\mathrm{X}_{\text {table }}$ was 11.070. And $\mathrm{X}_{\text {observed }}$ in the Pre-test control class was 8.8 and $\mathrm{X}_{\text {table }} 11.070$. then the $\mathrm{X}_{\text {observed }}$ in the Post-test control class was 9.96 and $\mathrm{X}_{\text {table }} 11.070$. It means the data was Normal distribution.

\section{Homogeneity Test}

The homogeneity test used to know whether each group had the same variance or not. It was tested by using F test. The summary of homogeneity testing can be seen as follow:

Table 3. Table of summary of homogeneity test

\begin{tabular}{ccccc}
\hline No. & Variable & $\mathrm{F}_{\text {observed }}$ & $\mathrm{F}_{\text {table }}$ & Conclusion \\
\hline 1 & Pre-test & 1.510 & 1.772 & Homogeneous \\
\hline 2 & Post-test & 1.184 & 1.772 & Homogeneous \\
\hline
\end{tabular}

Based on the table of homogeneity testing summary above, it could be concluded that $\mathrm{F}_{\text {observed }}$ for students' pre-test reading comprehension (1.510) and post-test reading 
comprehension (1.184) was lower than the ratio of $F_{\text {table }}$ (1.772). It means that both of the variances were homogeneous.

\section{Testing Hypothesis}

In order to see the effect of Shared Reading Strategy toward students' reading achievement, the data was analyzed by using T-test formula. Before the data was calculated by using t-test formula, the writer had find out the correlation between post-test in reading comprehension using correlation product moment.

\section{Formula 1.Product Moment}

$$
r=\frac{\sum x y}{\sqrt{\sum X^{2} Y^{2}}}
$$

(Sugiyono, 2013: 228)

Where:

$\mathrm{X}$ : The score of experimental class post-test

Y : The score of control class post-test

The process to find the correlation can be seen as follow:

$$
\begin{gathered}
r=\frac{\sum x y}{\sqrt{\sum X^{2} Y^{2}}} \\
=\frac{189200}{\sqrt{(216925)(168575)}} \\
=\frac{189200}{\sqrt{36568131875}} \\
=\frac{189200}{191227.958} \\
=0.98
\end{gathered}
$$

\section{T-test}

After the writer found the correlation of the two variables the writer would to find the t-test to know the effect of the media towards students' reading achievement by using ttest formula. 


\section{DISCUSSION}

The first findings showed that the students' mean score of reading comprehension at experimental class was better than students' mean score of reading comprehension at control class. It has supported from explanation in the second chapter where the writer conclude that Shared Reading Strategy was more effective learning environment.

Shared Reading Strategy can be applied on teaching skill, especially in reading skill. The researcher had conducted the research focuses on reading skill for seventh grade students of SMP Tunas Baru Jin Seung Batam. From the discussion above, it can be concluded that Shared Reading Strategy gave better result on reading comprehension.

By Shared Reading Strategy on teaching learning process could manifest considerable improvement in reading comprehension, and pronunciation. Related to the research finding, the students could focus and activate by the team work to analyze and determining main idea and supporting detail and finally they could answer the question from the text. Besides Shared Reading Strategy could encourage the students' motivation, ways of thinking, and creativity to read a text in English.

\section{REFERENCES}

Sugiyono. (2009). Statistika untuk penelitian. Bandung: Alfabeta.

Sugiyono. (2013).Statistika untuk penelitian.Bandung: Alfabeta.

Sugiyono. (2010).Metode penelitian pendidikan: Pendekatan kuantitatif, kualitatif, dan R\&D.Bandung: Penerbit Alfabeta. 